Sari Pediatri, Vol. 5, No. 1, Juni 2003: 4 - 11

\title{
Pubertas Terlambat pada Thalassemia Mayor
}

\author{
Diah Pramita, Jose RL Batubara
}

\begin{abstract}
Gangguan kelenjar endokrin akibat penimbunan besi pada pasien thalassemia mayor semakin sering ditemukan seiring dengan meningkatnya harapan hidup. Kegagalan pubertas merupakan komplikasi endokrin yang paling sering diikuti oleh amenore sekunder. Angka kejadian pubertas terambat pada thalassemia mayor bervariasi tergantung jenis kelamin, riwayat transfusi darah dan terapi kelasi besi yang pemah didapat, dan usia saat memulai terapi kelasi.

Para peneliti mendapatkan kejadian pubertas terlambat lebih sering terjadi pada lakilaki. Secara umum, penyebab pubertas terlambat dikiasifikasikan menjadi gangguan temporer sekresi gonadotropin, dan steroid seks, kegagalan poros hipotalamus-hipofisis dengan defisiensi sekresi gonadotropin dan kegagalan gonad primer. Gangguan tersebut diakibatkan oleh proses peroksidasi lipid oleh penimbunan besi di dalam sel-sel kelenjar hipofisis dan kerusakan di hipofisis mi menyebabkan sekresi gonadotropin menurun. Secara klinis keterlambatan pubertas pada perempuan umumnya keterlambatan pertumbuhan payudara dan rambut pubis, sedang pada lakilaki terjadi gangguan perkembangan testis. Penting untuk melakukan pemeriksaan hormonal untuk mengetahui fungsi poros hipotalamus-hipofisis-gonad. Tatalaksana thalassemia mayor dengan pubertas terlambat selain terapi pengganti hormonal, perlu diperhatikan status nutrisi, dan pemberian transfusi disertai terapi kelasi yang adekuat.
\end{abstract}

Kata kunci : thalassemia, pubertas, gonadotropin, hipofisis, hipotalamus.

P enyakit thalassemia sebagai penyakit hemolitik yang diderita seumur hidup, sehingga, membawa banyak sekali masalah bagi pasiennya.. Penimbunan besi dalam jaringan akan tetap terjadi dan semakin bertambah baik pada pasien yang mendapat atau tidak mendapat transfusi darah sehingga dapat menyebabkan disfungsi berbagai organ tubuh antara lain jantung, hati, dan kelenjar endokrin. ${ }^{1,2}$

Dengan makin meningkatnya angka harapan hidup pasien thalassemia mayor, gangguan kelenjar endokrin akibat penimbunan besi makin sering ditemukan. Efek

Dr. Diah Pramita: PPDS Ilmu Kesehatan Anak FKUI, Jakarta

\footnotetext{
Alamat korespondensi:

Dr. Jose RL. Batubara, Sp.A(K).

Subbagian Endokrinologi. Bagian Ilmu Kesehatan Anak FKUI-RSCM. Jl. Salemba no. 6, Jakarta 10430.

Telepon: 021-3100669. Fax.: 021-390 7743.
}

toksik besi ini terjadi pada hampir seluruh kelenjar endokrin terutama kelenjar hipofisis, gonad dan pankreas sedangkan kelenjar tiroid dan paratiroid jarang terkena. ${ }^{3,4}$ De Sanctis dalam penelitiannya tahun 1995 mendapatkan bahwa kegagalan pubertas terjadi pada 50\% kasus, merupakan komplikasi endokrin yang paling sering diikuti oleh amenore sekunder (23\%), hipotiroidisme primer $(6,2 \%)$, diabetes melitus $(4,9 \%)$ dan hipoparatiroidisme $(3,6 \%){ }^{4}$ Borgna-Pignatti dkk mendapatkan 38\% penderita thalassemia perempuan dan $67 \%$ penderita laki-laki mengalami keterlambatan pubertas dan hanya $19 \%$ wanita yang mengalami menarche. ${ }^{5}$

Mekanisme pasti toksisitas besi pada kelenjar endokrin belum jelas, namun terapi kelasi tampaknya berguna dalam mencegah atau menunda manifestasi endokrinopati. Terapi kelasi yang dilakukan sejak dini untuk mencegah penimbunan besi dapat membantu terjadinya pubertas normal pada 90\% kasus; sedangkan bila kelasi dimulai saat hemosiderosis sudah lanjut, pubertas normal hanya terjadi pada $38 \%{ }^{6}$ 
Sari Pediatri, Vol. 5, No. 1, Juni 2003

\section{Pubertas Terlambat pada Thalassemia Mayor}

\section{Definisi}

Pubertas terlambat adalah suatu keadaan tidak terdapatnya pertumbuhan payudara pada usia 13 tahun pada anak perempuan, atau jika dalam evaluasi mencapai masa waktu lebih dari 5 tahun antara saat pertumbuhan payudara sampai timbulnya menarke. Pada anak laki-laki pubertas terlambat apabila tidak tampak tanda pubertas (volume testis $<4 \mathrm{ml}$ ) pada usia 14 tahun, atau jika mencapai masa waktu lebih dari 5 tahun antara mulainya tanda pubertas sampai pertumbuhan genital yang lengkap. ${ }^{7,8}$

\section{Angka kejadian}

Pubertas terlambat merupakan komplikasi endokrin yang sering ditemukan pada kasus thalassemia mayor. Angka kejadiannya bervariasi tergantung dan jenis kelamin, riwayat transfusi darah dan terapi kelasi besi yang pernah didapat, dan usia saat memulai terapi kelasi. Di Turkei, Yesilipek mendapatkan 74,5\% kasus thalassemia berusia di atas 12 tahun mengalami pubertas terlambat. ${ }^{9}$ Di Perancis, Perignon melaporkan bahwa 50\% kasus thalassemia yang ditelitinya mengalami pubertas terlambat; ${ }^{10}$ sedangkan di Itali angka kejadian pubertas terlambat pada thalassemia berkisar antara $38-79,7 \% \%^{4,5,11}$

Para peneliti menyatakan bahwa pubertas terlambat lebih sering terjadi pada laki-laki. ${ }^{4,5,11}$ Dalam penelitiannya terhadap pasien thalassemia berusia 12 18 tahun, Cao dkk. mendapatkan 43,6\% pasien perempuan dapat mencapai tahap perkembangan Tanner 5 (T5) secara spontan sedangkan pada lakilaki hanya $20,3 \%$ yang mencapai tahap tersebut. ${ }^{11}$ Dalam penelitiannya tentang pertumbuhan dan perkembangan seksual pada thalassemia berusia di atas 10 tahun, Borgna-Pignatti mendapatkan 38\% kasus perempuan dan $67 \%$ laki-laki mengalami pubertas terlambat. ${ }^{4}$

\section{Etiologi}

Penyebab pubertas terlambat secara umum dapat diklasifikasikan menjadi 3 kelompok. ${ }^{8,12}$
- Gangguan temporer sekresi gonadotropin dan steroid seks.

Ini merupakan gangguan fungsional yang dapat terlihat pada beberapa keadaan, yang paling sering adalah constituional delay of puberty. ${ }^{8,12}$

- Kegagalan poros hipotalamus-hipofisis dengan defisiensi sekresi gonadotropin (hipogonadisme lipogonadotropik).Yang termasuk dalam kelompok ini antara lain kelainan pada susunan saraf pusat, sindrom Kalmann, sindrom Prader-Wilhi, sindrom Laurence-Moon-Biedl, defisiensi gonadotropin fungsional (penyakit sistemik kronis, malnutrisi, hipotiroidisme, diabetes melitus, anoreksia nervosa, dan lain-lain). ${ }^{8,12}$

- Kegagalan gonad primer yang mengakibatkan hilangnya kontrol umpan balik negatif dan gonadotropin yang menunjukkan peningkatan konsentrasi gonadotropin plasma (hipogonadisme hipergonadotropik). Yang termasuk dalam kelompok ini adalah sindrom Klinefelter, berbagai bentuk kegagalan testis dan ovarium primer, serta sindrom Turner. ${ }^{8,12}$

Penyebab pubertas terlambat pada thalassemia mayor adalah kegagalan poros hipotalamus-hipofisis yang mengakibatkan sekresi gonadotropin ( $\mathrm{LH}$ dan FSH) menurun. Akibatnya rangsangan terhadap gonad juga menurun yang mengakibatkan sekresi hormon seks berkurang. Ada berbagai faktor yang dapat mengganggu poros hipotalamus-hiposifis tersebut antara lain malnutrisi, derajat penyakit sistemik dan masalah-masalah spesifik yang terdapat pada thalassemia mayor seperti anemia kronis dan penimbunan besi. ${ }^{13}$

- Penimbunan besi

Penimbunan besi di kelenjar hipofisis merupakan penyebab primer pubertas terlambat pada thalassemia mayor. Akibat penimbunan besi di dalam sel-sel kelenjar hipofisis terjadi kerusakan dan kematian sel sehingga sekresi gonadotropin menurun.

- Anemia kronis

Landau dan kawan-kawan mendapatkan bahwa penderita thalassemia mayor yang jarang mendapat transfusi darah dengan kadar hemoglobin berkisar antara 5,4-6,3 g/dl hanya mengalami perkembangan pubertas yang minimal atau tidak sama sekali dibandingkan dengan penderita yang kadar hemoglobinnya lebih tinggi. ${ }^{13}$

- Malnutrisi 
Umumnya penurunan berat badan oleh sebab apapun juga hingga mencapai kurang dan $80 \%$ berat badan ideal dapat menyebabkan defisiensi gonadotropin. ${ }^{12}$ Peningkatan kembali berat badan dapat mengembalikan fungsi hipotalamus-hipofisisgonad dalam jangka waktu yang bervariasi.

\section{Patogenesis}

Pada thalassemia mayor terjadi penimbunan besi yang merupakan hasil kombinasi antara transfusi darah berulang, peningkatan absorpsi besi dalam usus karena eritropoesis yang tidak efektif, anemia kronis serta proses hemolisis. ${ }^{1}$ Pemberian transfusi darah secara teratur menurunkan absorpsi besi secara bermakna tetapi menyebabkan penimbunan besi di dalam sistem retikuloendotelial. ${ }^{14}$ Penimbunan besi juga terjadi pada organ-organ lain termasuk kelenjar endokrin. Setiap unit suspensi sel darah merah $(200 \mathrm{ml})$ mengandung $200 \mathrm{mg}$ besi.

Besi yang tidak terpakai akan berikatan dengan apoferitin untuk disimpan sebagai bentuk yang nontoksik yaitu feritin. ${ }^{15}$ Molekul-molekul feritin pada akhirnya akan berkelompok dan dihancurkan oleh lisosom menjadi granul-granul yang lebih kecil dengan konsentrasi besi yang lebih tinggi yaitu hemosiderin, yang menumpuk dalam liposom. Pada keadaan normal feritin tidak menimbulkan kerusakan patologis. Namun akumulasi hemosiderin menyebabkan terlepasnya enzim hidrolitik dan lisosom yang bersifat toksik terhadap sel. ${ }^{14}$ Besi yang tidak terikat oleh transferin ini disebut nontransferin bound iron/free serum iron pool yang dapat mengakibatkan keadaan toksik dan dapat memacu pembentukan radikal hidroksil bebas (HO) ${ }^{16}$

Radikal hidroksil bebas yang terbentuk dapat menyerang semua makromolekul biologis, menyebabkan depolimerisasi polisakarida, pemecahan rantai DNA, inaktivasi enzim, dan memicu reaksi peroksidasi lipid. ${ }^{16}$ Reaksi peroksidasi lipid dan berbagai organel selular seperti mitokondria, lisosom dan membran sarkoplasma dapat menyebabkan kerusakan membran dan terbentuknya bermacam-macam produk peroksida yang reaktif dan bersifat toksik ${ }^{15,14,17}$ Di samping itu juga terjadi perubahan struktur membran yang mengakibatkan gangguan fungsi seluler organel. ${ }^{15,14,17}$ Kerusakan oksidatif pada protein dibuktikan melalui percobaan in vitro, yaitu mengakibatkan hilangnya aktivitas enzimatik sehingga fungsi seluler menjadi terganggu. ${ }^{28}$
Tubuh memiliki beberapa mekanisme pertahanan seluler untuk mencegah terjadinya kerusakan sel akibat peroksidase dapat menghambat aktivitas superoksida secara langsung. Sedangkan enzim fosfolipid hidroperoksida glutation peroksidase, vitamin E dan vitamin $\mathrm{C}$ dapat mencegah terjadinya reaksi peroksidasi lipid yang berkepanjangan. Bila semua mekanisme pertahanan tersebut gagal, sel dapat mengalami kerusakan berat yang dapat mengakibatkan kematian sel tersebut. ${ }^{16}$ Akibat penimbunan besi di dalam sel-sel kelenjar hipofisis proses peroksidasi lipid yang akan mengakibatkan kerusakan dan kematian sel. Akhirnya akan terjadi pembentukan kolagen dan fibrosis. ${ }^{17}$ Kerusakan di hipofisis ini menyebabkan sekresi gonadotropin (LH dan FSH) menurun. Akibatnya rangsangan terhadap gonad juga menurun yang rnengakibatkan sekresi hormon seks berkurang.

Kelenjar hipofisis ternyata sangat sensitif terhadap radikal bebas dan paparan terhadap radikal bebas ini pada masa kanak-kanak dini dapat menyebahkan kerusakan pada kelenjar tersebut. ${ }^{4,18,20}$ Pemeriksaan histologis kelenjar hipofisis pada penderita thalassemia mayor saat diautopsi menunjukkan bahwa pada kelenjar hipofisis selain hemosiderosis derajat ringan sampai sedang juga terjadi fibrosis dan penurunan jumlah sel. ${ }^{19}$ Sedangkan pada pemeriksaan MRI penderita thalassemia mayor dengan pubertas terlambat didapatkan adanya sel yang kosong pada beberapa penderita, ukuran kelenjar hipofisis yang sangat mengecil, tangkai hipofisis yang menipis, dan bukti adanya deposit besi pada kelenjar hipofisis. ${ }^{21}$

Selain di hipofisis, penimbunan besi juga dapat ditemukan pada gonad. Hal ini didukung oleh pemeriksaa histologis dari berbagai kelenjar endokrin yang menunjukkan adanva penimbunan besi yaitu antara lain pada testis dan ovarium. Pada ovarium didapatkan hemosiderosis minimal, penurunan jumlah folikel primordial, dan kapsul yang tebal. Pada testis terdapat testis yang imatur, gangguan pematangan spermatogonia, penurunan jumlah sel Leydig dan hialinisasi membran basal tubulus seminiferus di tempat sehagian besar hesi terdapat pada jaringan interstisial. ${ }^{19}$

\section{Gambaran klinis}

Perkembangan pubertas pada thalassemia mayor sangat bervariasi. Perempuan umumnya mengalami keterlambatan pertumbuhan payudara dan rambut 
pubis serta amenore primer maupun sekunder, walaupun ada juga yang mengalami pubertas normal. Pada laki-laki biasanya terjadi gangguan perkembangan testis yaitu volume testis $<4 \mathrm{ml} .{ }^{19}$

Pada sebagian besar kasus perempuan, pertumbuhan payudara dan rambut pubis umumnya hanya mencapai tahap Tanner 1 (Ti) atau T2. ${ }^{18,19,22,23}$ Menarche hanya terjadi pada sebagian kecil kasus, berkisar antara $19-25 \%$ dan berlangsung pada usia rata-rata 14 tahun $^{11,19}$ Menarche umumnya terjadi pada pasien yang telah mencapai tahap 3 pada perkembangan payudara (M3) sedangkan pasien yang mencapai tahap MI atau M2 jarang atau hampir tidak ada yang mengalami menarche. Pada wanita yang telah mengalami menstruasi banyak yang akhirnya menderita amenore sekunder, yaitu 23-38\%. ${ }^{11,18,19}$ Amenore sekunder ini umumnya terjadi dalam 10 tahun setelah menarche. Selain itu juga dapat terjadi menstruasi yang tidak teratur dan oligomenore. Pada thalassemia laki-laki, volume testis rata-rata umumnva berada di bawah persentil 10 kurva laki-laki normal. ${ }^{19}$ Perkembangan pubertas terhenti pada 15,79\% penderita. Pada sebagian besar penderita tersebut, perkembangan testis terhenti setelah mencapai volume 6-8 $\mathrm{ml}$. Sedangkan pada yang mengalami perkembangan pubertas secara komplit, 1,6\% menderita hipogonadisme sekunder.

\section{Gambaran laboratorium}

\section{Kadar hormon}

Pemeriksaan hormonal penting untuk mengetahui fungsi poros hipotalamus-hipofisis-gonad pada penderita thalassemia mayor. Untuk membedakan antara gangguan fungsi Hipotalamus dan hipofisis, Kletzky dkk. melakukan penelitian pada penderita thalassemia yang mengalami pubertas terlambat dengan memberikan priming GnRH eksogen selama 7 hari yang diikuti tes stimulasi GnRH. ${ }^{20}$ Ternyata kadar basal LH dan FSH serta respons LH dan FSH terhadap stimulasi GnRH akut dan kronik rendah, ini menunjukkan bahwa terdapat kelainan hipofisis primer serta tidak adanya cadangan gonadotropin pada hipofisis. Peneliti-peneliti lain juga mendapatkan bahwa disfungsi gonadotropin hipofisis merupakan penyebab utama pubertas terlambat pada thalassemia mayor. ${ }^{19,24}$
Selain kadar LH dan FSH yang rendah, kadar estradiol dan testosteron serum juga rendah, ${ }^{19,24}$ seperti kadar prapubertas. Anoussakis dkk. mendapatkan bahwa kurangnva sekresi LH dan FSH serta rendahnya kadar testosteron serum pada penderita thalassemia mayor yang mengalami pubertas terlambat menggambarkan kurangnya stimulasi testis oleh hipofisis, dan bukan disebabkan kerusakan pada testis. ${ }^{24}$ Ini dibuktikan dengan adanya respons testis yang normal terhadap pemberian HCG sampai usia 11 tahun yaitu berupa peningkatan kadar testosteron serum.

Sebaliknya, Soliman dkk. mendapatkan hasil yang berbeda. Dalam penelitian yang mereka lakukan terhadap 10 penderita thalassemia laki-laki dengan pubertas terlambat, didapatkan respons testosteron serum yang rendah terhadap pemberian HCG 2500 $\mathrm{U} / \mathrm{m}^{2} /$ dosis selama 6 bulan. Ini menunjukkan adanva atrofii testis yang berat dan/atau kegagalan sekunder terhadap siderosis. ${ }^{21}$

Kasus thalassemia mayor yang telah mengalami menstruasi, didapatkan bukti terjadi penurunan sekresi gonadotropin pulsatil. ${ }^{22} \mathrm{Hal}$ Ini merupakan indikasi adanya sedikit kerusakan pada mekanisme penghasil pulsus GnRH di hipotalamus. Sedangkan gonadotiroph hipofisis mengalami kerusakan yang lebih berat dibandingkan hipotalamus yang terlihat dan rendahnya kadar gonadotropin basal dan pasca stimulasi GnRH selama siklus menstruasi.

Pada dasarnya pasien thalassemia yang mengalami amenore sekunder menderita defek hipotalamus dan hipofisis, ${ }^{22}$ namun walaupun fungsi hipofisis terganggu gonadotroph masih dapat mentransmisikan pulsus GnRH secara efektif sehingga penderita memiliki parameter puncak gonadotropin yang normal walaupun sedikit rendah. Ini menunjukkan bahwa pasien tersebut memiliki aksis hipotalamus-hipofisis yang utuh walaupun cadangannya menurun. Cadangan yang menurun ini menyebabkan mereka mungkin akan mengalami amenore sekunder di kemudian hari.

Chatterjee mendapatkan bahwa dalam 2 tahun setelah onset amenore, fungsi hipotalamus-hipofisis akan mengalami deteriorasi yang ditandai dengan menurunnya respons gonadotropin terhadap stimulasi $\mathrm{GnRH}$, dan terdapatnva defek pulsus pulsatil yang merupakan karakteristik kerusakan hipotalamus. ${ }^{23}$ Gangguan kompleks hipotalamus-hipofisiss ini berjalan progresif secara ireversibel sehingga semua pasien thalassemia mayor dalam penelitian ini mengalami amenore sekunder. Dalam 5-6 tahun 
setetah onset amenore sekunder, sekresi gonadotropin pulsatil menjadi apulsatil dan kadar gonadotropin setelah stimulasi $\mathrm{GnRH}$ menurun secara bermakna dibandingkan pada awal penelitian dan 18-24 hulan setelah menarche. Ini berarti bahwa walaupun penderita thalassemia mayor mendapat terapi kelasi besi secara intensif, terjadi kerusakan progresif dan berat pada kompleks GnRH-gonadotropin.

Gangguan fungsi gonad juga didapatkan pada hampir semua pasien thalassemia dengan amenore sekunder yang telihat dan rendahnya kadar estradiol basal dan tidak adanya respons terhadap pemberian HMG. ${ }^{25}$

\section{Diagnosis}

Pada anamnesis penting ditanyakan usia saat diketahui menderita thalassemia, jenis thalassemia, riwayat mendapat transfusi dan kelasi secara teratur, usia saat mulai mendapat terapi kelasi, dan pengukuran kadar feritin. Selain itu untuk rnenyingkirkan penyebab lain dari pubertas terlambat, perlu ditanyakan juga tentang riwayat perkembangan pubertas dalam keluarga, data pertumbuhan sebelumnya, dan riwayat penyakit, serta perkembangan terdahulu.

Pada pemeriksaan fisis dilakukan pengukuran berat badan dan tinggi badan yang tepat, penilaian organomegali, dan pemeriksaan status pubertas seperti pertumbuhan payudara, rambut pubis dan aksila, serta ukuran panjang penis dan testis. Pemeriksaan laboratorium meliputi darah periter lengkap, kadar feritin serum dan kadar hormon dalam serum yaitu LH, FSH, testosteron (pada laki-laki) dan estradiol (pada wanita) baik basal maupun setelah pemberian GnRH, HCG, atau HMG. Pemeriksaan radiologis tulang untuk menentukan usia tulang penting dilakukan untuk mengetahui usia biologis dan memperkirakan saat terjadinya maturasi pubertas. Pada perempuan pubertas seharusnya dimulai ketika usia tulang mencapai 10-11 tahun dan 12,5 tahun pada laki-laki. Selain itu bila diperlukan dapat dilakukan pemeriksaan USG genitalia interna, CT scan kepala dan MRI kepala.

\section{Tata laksana}

Dalam pengobatan thalassemia mayor dengan pubertas terlambat, langkah-langkah pertama yang harus diperhatikan adalah memperbaiki status nutirisi, meningkatkan keadaan kesehatan secara umum, dan pemberian transfusi serta terapi kelasi yang adekuat. ${ }^{26}$ Sedangkan untuk mengatasi hipogonadisme dianjurkan terapi pengganti hormonal.

\section{Terapi kelasi}

Dalam beberapa penelitian disebutkan bahwa terapi kelasi yang dimulai sebelum usia pubertas dapat meningkatkan potensi tercapainya maturasi seksual yang normal. ${ }^{5,6}$ Bronspiegel-Weintrob dkk. meneliti pengaruh terapi kelasi dini terhadap maturasi seksual. Dalam penelitian tersebut, subyek dibagi menjadi 2 kelompok. Kelompok A mendapat terapi desferioksamin sebelum usia 10 tahun (rata-rata 7,5 $\pm 1,8$ tahun) sedangkan kelompok B setelah 10 tahun (14,4 \pm 4,7 tahun). Desferioksamin diberikan selama 9 tahun dengan dosis $50 \mathrm{mg} / \mathrm{kgBB} /$ hari setiap hari secara subkutan dengan pompa infus. Kadar hemoglobin dipertahankan di atas $10,5 \mathrm{~g} / \mathrm{dl}$. Tenyata $90 \%$ kasus yang mendapat terapi kelasi teratur sejak usia rata-rata 7,5 tahun (kelompok A) akan mencapai pubertas normal sedangkan bila terapi dimulai pada usia rata-rata 14,4 tahun hanya 38\% yang mencapai pubertas normal. ${ }^{6}$ Peneliti lain mendapatkan bahwa pasien thalassemia mayor wanita yang mendapat terapi kelasi secara teratur mengalami perkembangan payudara yang normal, serta kadar estradiol, pola menstruasi, dan ukuran ovarium yang juga normal. Kadar feritin mereka berkisar antara $1200-2100 \mathrm{ng} / \mathrm{ml} .^{22}$ Hal tersebut di atas mungkin disebabkan karena kelenjar endokrin sangat sensitif terhadap toksisitas besi sehingga jumlah yang sangat sedikitpun, yang terakumulasi dalam tahun-tahun pertama kehidupan, menyebabkan kerusakan jaringan yang ireversibel. ${ }^{5}$

\section{Terapi Pengganti Hormonal}

Selama ini terdapat kontroversi mengenai usia saat terapi dimulai dan dosis yang diberikan. Terdapat ahli yang menganjurkan agar terapi pengganti ini ditunda hingga mencapai usia saat gangguan pematangan seksual dapat dideteksi dengan mudah. Alasannya adalah bahwa hipogonadisme pada thalassemia biasanya tampak sebagai keterlambatan pematangan seksual. Sedangkan para pendukung terapi dini menitikberatkan pada keuntungan-keuntungan psikologis dari terapi dini karena selain membantu pematangan seksual juga dapat memperbaiki kecepatan tumbuh dan tinggi badan akhir. ${ }^{3}$ 
Pada anak wanita terapi pengganti hormonal diberikan pada yang telah berusia lebih dan 13 tahun dengan usia tulang lebih dari 11 tahun. Pada anak lakilaki terapi diberikan pada yang telah berusia lebih dari 14 tahun dengan usia tulang lebih dan 12 tahun. ${ }^{3}$

\section{Terapi pada anak laki-laki}

\section{Testosteron}

Tujuan terapi pengganti hormonal pada laki-laki antara lain adalah untuk merangsang atau mempertahankan fungsi seksual dan karakteristik seks sekunder. ${ }^{27,28}$ Testosteron enantat merupakan salah satu preparat pilihan karena memiliki masa kerja yang lama dan tidak bersifat toksis terhadap hati. Landau dkk. melaporkan bahwa pemberian testosteron dapat meningkatkan pertumbuhan rambut pubis dan ukuran testis secara bermakna serta menyebabkan terjadinya pacu tumbuh. ${ }^{13}$ Roth dkk. juga mendapatkan bahwa pemberian testosteron dosis rendah selama 3-13 bulan pada penderita thalassemia laki-laki saat usia pubertas dapat menyebabkan terjadinya pacu tumbuh. ${ }^{29}$ Dosis inisial testosteron enantat adalah 50-100 mg setiap 24 rninggu yang diberikan secara intramuskular. Setelah 6-12 bulan dosis dinaikkan bertahap selama kurun waktu 3-4 tahun hingga mencapai dosis pengganti dewasa yaitu $200 \mathrm{mg}$ setiap 3 minggu. ${ }^{5}$

Untuk memantau terapi dilakukan pengukuran kadar testosteron serum. Satu minggu setelah penyuntikan, kadar testosteron serum seharusnya berada pada daerah pertengahan normal. Bila 14 hari sejak penyuntikan kadarnya rendah, interval pemberian dapat dipersingkat. ${ }^{27}$ Pengobatan dengan testosteron dapat mengakibatkan efek samping berupa peningkatan berat badan, akne, ginekomastia, hipertensi, edema tungkai, gangguan fungsi hati, dan gangguan hemostasis berupa agregasi trombosit. Oleh karena itu diperlukan pemantauan pemeriksaan fisis dan laboratorium untuk mencegah terjadinva efek-efek samping tersebut. ${ }^{27,28}$

\section{Gonadotropin}

Pada beberapa penelitian pemberian Human Chorionic Gonadotropini (bCG) dan Human Menopausal Gonadotropin ( $h M G$ ) dapat memperbaiki spermatogenesis dan produksi testosteron. Dosis hCG yang diberikan adalah 500-5000 IU intramuskular sebanvak 2-3 kali dalam seminggu selama 6 bulan. ${ }^{30}$ Bila pada akhir bulan ke 6 tidak didapatkan sperma pada ejakulat, maka terapi ditambah dengan hMG 75 unit intramuskular yang diberikan 2 kali dalam seminggu. Bila setelah 6 bulan berikutnya tetap tidak ada respons, terapi dilanjutkan dengan hCG 200 U, 2 kali seminggu dan hMG 150 U, 3 kali seminggu ${ }^{30}$ Selama terapi dilakukan terapi dilakukan pemantauan terhadap keadaan klinis, kadar testesteron dan analisis semen setiap 3 bulan. Penyesuaian dosis dilakukan berdasarkan kadar testosteron dan keadaan klinis.

Morte dkk. menyatakan bahwa pemberian hCG efektif dalam merangsang dan mempertahankan karakteristik seks sekunder. ${ }^{31}$ Dalam penelitiannya sejumlah pasien thalassemia mayor laki-laki berusia rata-rata 17,6 tahun diobati dengan hCG. Dosis awal 1000 IU yang diberikan dua kali dalam seminggu. Dalam 12 bulan terjadi kemajuan dalam tahap perkembangan pubertas dari Tanner 1,2 dan 3 menjadi Tanner 4 dan 5. Selain itu analisis semen menunjukkan adanya perbaikan setelah 12 bulan terapi yaitu dari aspermia menjadi azospermia dan oligospermia. Sedangkan Soliman dkk. Mendapatkan bahwa setelah pemberian hCG $2500 \mathrm{U} / \mathrm{m}^{2} /$ dosis selama 6 bulan pada penderita thalassemia mayor dengan pubertas Terlambat, $50 \%$ penderita tidak menunjukkan adanya pembesaran ukuran testis atau perubahan genitalia. ${ }^{21}$ Pada kasus demikian pengobatan testosteron mungkin lebih baik dibandingkan terapi hCG. Terapi ini sebaiknya diberikan pada saat yang tepat untuk menginduksi perkembangan seksual dan membantu percepatan tumbuh linier dan peningkatan mineral tulang.

\section{Terapi pada anak perempuan}

Terapi pengganti pada anak perempuan terdiri dari estrogen terkonjugasi dan progesterone. ${ }^{3,7}$ Terapi dimulai dengan pemberian estrogen terkonjugasi 0,3 mg setiap hari selama 6-9 bulan. Setelah 9 bulan atau setelah terjadi menarche diberikan terapi siklus estrogen-progesteron. Estrogen diberikan untuk 21 hari pertama. Pada 10 hari terakhir (hari ke 12-21) ditambahkan progesterone yaitu berupa medroksi progesteron ( 5 atau $10 \mathrm{mg} /$ hari) atau noretindron (5 $\mathrm{mg} /$ hari). Pada hari ke 22 hingga akhir bulan, penderita tidak mendapat obat. Pada hari pertama bulan berikutnya, walaupun menstruasi belum berhenti, estrogen mulai diberikan lagi. Dosis estrogen dinaikkan 
bertahap selama kurun waktu 2-3 tahun hingga mencapai dosis akhir $2,25 \mathrm{mg} / \mathrm{hari}$.

Gokcfen dkk. melakukan penelitian tentang perkembangan pubertas pada pasien thalassemia wanita. ${ }^{22}$ Mereka mendapatkan bahwa pasien dengan hipogonadisme yang mendapat terapi pengganti hormonal saat berusia 17-49 tahun mengalami kemajuan perkembangan pubertas dan Tanner 1-2 menjadi Tanner 3-4 serta mengalami menarche. Sedangkan Landau dkk. mendapatkan bahwa pasien thalassemia wanita berusia di atas 18 tahun yang mendapat terapi pengganti hormonal selama 3 tahun mengalami perkembangan payudara yang progresif dan menstruasi yang teratur selama terapi. ${ }^{13}$ Selama 3 bulan pertama pasien mendapat estradiol valerat $10 \mathrm{mg}$ intramuskular setiap 2 minggu, untuk 8 bulan berikutnya diberikan 0,625-1,25 mg estrogen terkonjugasi setiap hari untuk 21 hari pertama pada tiap bulannya.

Preparat hormonal ini tidak boleh diberikan pada pasien dengan diabetes melitus, kelainan hati, hiperkolesterolemia, hipertensi, dan bila epifisis sudah menutup. Efek samping yang dapat timbul pada pemberian terapi hormonal ini antara lain peningkatan berat badan, hipertensi, perubahan toleransi glukosa, perdarahan tidak teratur, malaise, edema, depresi, acne, dan hirsutisme. Selain itu pemberian terapi ini dapat meningkatkan usia tulang dan menyebabkan penutupan epifisis bila diberikan secara terus menerus. ${ }^{32}$ Untuk mencegah hal tersebut maka estrogen diberikan dalam dosis rendah sehingga tidak mempengaruhi tinggi badan akhir.

\section{Prognosis}

Prognosis akan lebih baik bila pasien mendapat transfusi darah dan terapi kelasi besi secara teratur sejak dini. Pada pasien thalassemia wanita, kegagalan pubertas total merupakan tanda prognosis yang buruk. Demikian pula halnya pada pasien yang mengalami amenore sekunder oleh karena kemungkinan penyembuhan spontan sangat keciI. ${ }^{23}$ Induksi ovulasi dan kehamilan dapat dilakukan pada kasus thalassemia mayor dengan fungsi ovarium sang masih intak.

Sebelum era dimulainya strategi pemberian transfusi darah dan terapi kelasi yang intensif, kehamilan sangat jarang ditemukan pada thalassemia mayor. Selama 2 dekade terakhir, dengan meningkatnya harapan hidup, pertumbuhan dan fertilitas akibat terapi yang intensif, kehamilan pada thalassemia mayor makin sering ditemukan.

Aessopos dkk. melakukan penelitian terhadap 19 penderita thalassemia mayor yang mengalami kehamilan secara spontan. ${ }^{46}$ Semua kasus ini telah menjalani transfusi secara teratur dengan kadar hemoglobin dipertahankan sekitar $10 \mathrm{~g} / \mathrm{dl} \mathrm{dan}$ mendapat terapi kelasi $40 \mathrm{mg} / \mathrm{kgBB}$ selama 5 hari dalam seminggu, sehingga menarche terjadi spontan. Dua orang penderita mendapat terapi pengganti hormonal selama 12 dan 18 bulan.

\section{Daftar Pustaka}

1. Petunjuk diagnosis dan tata laksana kasus talasemia. Subbagian Hematologi. Jakarta 1997. h. 1-3.

2. Wahidiyat I. Thalassemia dan penanganannya. Dalam: Wahidiyat I. Gatot D, Mangunatmadja I, penyunting. Perkembangan mutakhir penyakit hematotogi onkologi anak. PKB IKA XXIV FKUI 1991. Jakarta: Bagian IKA FKUI, 1991. h. 109-112.

3. Kattamis CA, Kattamis AC. Management of thalassemias: Growth and development, hormone substitution, vitamin supplementation, and vaccination. Semin Hematol 1995; 32:269-79.

4. De Sanctis $\backslash$. Multicenter study on prevalence of endocrine complications in thalssemia major. Clin Endocrinol 1995; 42:581-6.

5. Borgna-Fignatti C, De Stefano F, Zonta L, Vullo C, De Sanctis V, Melevendi C. Growth and sexual maturation in thalassemia major. J Pediatr 1985; 106:150-4.

6. Bronspiegel-Weintrob N, Oliveri NF, Tyler B, Andrews DF, Freedman MH, Holand FJ. Effect of age at the start of iron chelation therapy on gonadal function in $\mathrm{b}$ thalassemia major. N Engl J Med 1990; 323:713-9.

7. Lee PA. Disorder of puberty. Dalam: Lifshitz F, penyunting. Pediatric endocrinology. Edisi ke-3. New York Marcel Dekker Inc. 1996. h. 179-95.

8. Bourguignon JP. Delayed puberty and hypogonadism. Dalam: Bertrand I. Rappaport, Sizonenko PC, penyunting. Pediatric endocrinology: Physiology, pathophysiology, and clinical aspects. Edisi ke-2. Baltimore: Williams \& Wilkins, 1993. h. 404-19.

9. Yesilipek MA. Growth and sexual maturation in children with thalassemia mayor. Haematologica 1993; 78:30-3.

10. Perignon F. Growth and endocrine function in major thalassemia. Arch Fr Pediatr 1993; 50:657. Abstrak.

11. Cao A, Galanello R, Rosatelli NIC, Argiole F, Virgillis SD. Clinical experience of management of thalassemia: The Sardinian experience. Semin Hematol 1996; 33:66-74.

12. Grumbach MM, Styne DM. Puberty: Ontogeny, neuroendocrinology. physiology and disorders. Dalam: Wilson JD. Foster DW, penyunting. Textbook of encocrinology. Edisi ke-8. Philadelphia: WB Saunders company, 1992. h. 1139- 
221.

13. Landau H, Gross V. Dagan I, Palti Z, Rachmilewitz EA, Spitz IM. Growth and sexual development before and after sex steroid therapy in patients with thalassemia major. Arch Intern Med 1984; 144:2341-6.

14. Bacon BR, Brown KE. Iron metabolism and disorders of iron overload. Dalam: Kaplowitz N, penyunting. Liver and biliary disease. Edisi ke-2. Baltimore: Williams \& Wilkins, 1996. h. 349-62.

15. Bridges KE. Iron metabolism and sideroblastic anemia. Dalam: Nathan DG, Oski FA, penyunting. Hematology of infancy and childhood. Edisi ke-4. Philadelphia: WB Saunders, 1993. h. 391-412.

16. McCord JM. Iron, free radicals, and oxidative injury. Semin Hematol: Iron overloading disorders and iron regulation 1998; 35:5-24.

17. Halliday JW, Powell LW. Hemochromatosis and other diseases associated with iron overload. Dalam: Lauffer $\mathrm{RB}$, penyunting. Iron and human disease. Boca Raton: CRC Press, 1992. h. 132-55.

18. Mc Intosh N. Endocrionopathy in thalassemia major. Arch Dis Child 1976; 51:195-200.

19. Costin G, Kogut M, Hyman CB, Ortega J. Endocrine abnormalities in thalassemia major. Am J Dis Child 1979; 133:497-502.

20. Kletzky OA, Costin C, Marrs RP, Bernstein G, March CM, Mishell DR. Gonadotropin insufficiency in patients with thalassemia major. J Clin Endocrinol Metab 1979; 48:901-5.

21. Soliman AT, elZalabany MM, Ragab M, Abdel Fatah M, Hassab H, Rogol AD. Spontaneous and GnRH-provoked gonadotropin secretion and testosteron respons to human chorionic gonadotropin in adolescent boys with thalassemia major and delayed puberty. J Trop Pediatr 2000; 46(2):79. Abstrak.

22. Gockfen O, Malyali D, Kanadikirik E, Azizlerli FL. Pubertal development in female thalassemics. Dalam:
Ando S. Brancati C, penyunting. Endocrine Disorders in thalassemia. Physiopathological and therapeutical aspects. Edisi ke-2. Berlin: Springer Verlag: 1995. h. 141-3.

23. Chatterjee R, Katz M, Cox TF, Porter JB. Prospective study of the hypothalaic-pituitary axis in thalassemic patients who developed secondary amenorrhoea. Clin Endocrinol 1993; 39:287-96.

24. Anoussakis CH, Alexiou D. Abatzis D, Bechrakis C. Endocrinological investigation of pituitary gonadal axis in thalassemia major. Acta Paediatr Scand 1977; 66:49-51.

25. De sanctis V, Vullo C, Katz M, Wonke B, Hoffbrand AV, Bagni B. Hypothalamic-pituitary-gonadal axis in thalassemic patients with secondary amenorrhea. Obstet Gynecol 1988; 72:643-7.

26. Mc Donagh KT, Nienhuis AW. The thalassemias. Dalarn: Nathan DG, Oski FA, penyunting. Hematology of infancy and childhood. Edisi ke-4. Philadelphia: WB Saunders, 1993. h. 784-8, 836-47.

27. Bagatell CJ, Bremner WJ. Androgens in men, uses and abuses. N Eng J Med 1996; 334:704-17.

28. Bhasin S. Bremner WJ. Clinical review: Emerging issues in androgen replacement therapy. Clin Endocrinol Metab 1997; 82:3-8.

29. Roth C. Short stature and failure of pubertal development in thalassemia major. Evidence for hypothalamic neurosecretory dysfunction of growth hormone secretion and delective pituitary gonadotropin secretion. Eur J Pediatr 1997; 156:777-83.

30. De Sanctis, Wonke B. Growth and endocrine complications in thlassaemia. Roma: Mediprint, 1998. h. 7-42.

31. Morte D. Induction of puberty and maintenance of secondary characteristics in males with thalassemia major. Arch Ital Urol Androl 1993; 65:193-6.

32. Styne DM. Puberty. Dalam: Greenspan FS, penyunting. Basic and clinical endocrinology. Edisi ke-3. San Fransisco; Lange;1991. h. 519-40. 